\title{
Effect of Creatine Monohydrate Supplementation on Various Hematological and Serum Biochemical Parameters of Male Albino Mice following Neonatal Hypoxia-Ischemia Encephalopathy
}

\author{
Shahid Iqbal, ${ }^{1}$ Nabia Nazir, ${ }^{1}$ Quratulane Gillani,, ${ }^{1}$ Atif Akbar, ${ }^{2}$ and Furhan Iqbal ${ }^{1}$ \\ ${ }^{1}$ Zoology Division, Department of Zoology, Institute of Pure and Applied Biology, Bahauddin Zakariya University, \\ Multan 60800, Pakistan \\ ${ }^{2}$ Department of Statistics, Bahauddin Zakariya University, Multan 60800, Pakistan
}

Correspondence should be addressed to Furhan Iqbal; furhan.iqbal@bzu.edu.pk

Received 2 August 2013; Accepted 25 August 2013

Academic Editors: F. A. Simmen and A. Surguchov

Copyright (C) 2013 Shahid Iqbal et al. This is an open access article distributed under the Creative Commons Attribution License, which permits unrestricted use, distribution, and reproduction in any medium, provided the original work is properly cited.

\begin{abstract}
Background. Present study was designed to report the effect of $2 \%$ creatine monohydrate supplementation for 8,12 and 15 weeks on hematology and serum biochemical profile of male albino mouse following hypoxic ischemic insult on postnatal day 10. Methods. 66 Blood samples $(2 \%$ creatine monohydrate supplemented $(N=34)$ and unsupplemented $(N=32)$ ) were analyzed for various hematological (blood glucose, packed cell volume, total WBC count, total RBC count) and serum biochemical parameters (cholesterol, AST, ALT, HDL, LDL, total protein, triglycerides). Results. ALT had higher concentrations in mice feeding on normal diet for $8(P>0.01)$ and 12 weeks $(P>0.01)$ following asphyxia and in 12 weeks treatment without asphyxia $(P=0.006)$ when compared with the creatine supplemented mice. LDL $(P=0.011)$ and cholesterol $(P>0.01)$ had higher concentrations in mice on normal diet for 12 weeks following hypoxia ischemia. Cholesterol $(P>0.01)$ in 12 and glucose $(P=0.006)$ in 15 week treatment group had significantly lower concentrations in creatine supplemented male albino mice when compared with untreated group following hxpoic-ischemic insult. Conclusion. We concluded that creatine supplementation following hypoxic ischemic insult helps in maintain the normal blood chemistry.
\end{abstract}

\section{Introduction}

Hypoxic ischemic encephalopathy (HIE) is a common cause of neonatal brain injury with an incidence rate of 2 in 1000 term infants in the developed world. $15-20 \%$ of infants with HIE die in neonatal period, and $25-30 \%$ of survivors are left with permanent neurodevelopmental abnormalities [1]. Hypoxic ischemic injury in neonates is caused by variety of conditions such as birth asphyxia, cardiac arrest, or respiratory failure. Lack of regenerative ability in the central nervous system after injury is considered to be its fundamental cause [2]. HIE can lead to postneonatal neurological sequelae, that is, cerebral palsy, mental retardation, learning disability, and epilepsy [3-6]. Data from Pakistan has shown that it is one of the leading causes for admission in a neonatal unit [7]. It has also been shown that most causes of neonatal morbidity in Pakistan are preventable [8].

Creatine (Cr) and phosphocreatine (PCr) play an essential role in the storage and transmission of phosphate bound energy [9]. Creatine is an amino acid derivative that is found naturally, to small extent, in human body [10]. Liver, pancreas, and kidney synthesize approximately $2 \%$ of the total body creatine while $98 \%$ of creatine is taken with food. Creatine is naturally present in meat and to some extent in green leaved vegetables. $60 \%$ of creatine found in the body is in the form of creatine phosphate [11]. Creatine has been shown to be neuroprotective in various neurological conditions [12]. Acute oral creatine supplementation reduces mental fatigue on a serial calculation task [13]. Creatine shows protective effects in models of acute neuronal damage, such as 
traumatic brain injury [14] and stroke [15]. In animal models of neurodegenerative disease, creatine monohydrate supplementation has been shown to improve brain functioning, reduce oxidative stress, and attenuate neuronal degeneration [16-18]. Despite of extensive studies on creatine and its neuroprotective effects, little information is available regarding the effect of creatine monohydrate supplementation on blood chemistry following hypoxic ischemic encephalopathy.

Present study was conducted to study the effect of $2 \%$ creatine monohydrate supplemented or normal rodent diet on selective parameters of albino mice blood profile under normal conditions as well as following neonatal hypoxic ischemic encephalopathy (HIE) at postnatal day 10.

\section{Materials and Methods}

2.1. Experimental Animals. Male albino mice were used as experimental animals and maintained in cages filled with wood chips at animal facility, Institute of Pure and Applied Biology (IPAB), Bahauddin Zakariya University, Multan, Pakistan. In breeding colony, standard mouse diet and water were available. Room temperature was maintained at $22 \pm$ $1^{\circ} \mathrm{C}$. The light/dark rhythm was maintained at $14: 10$ hours. The room was illuminated with artificial light at an intensity of about $200 \mathrm{~W}$ from 8 a.m. to 7 p.m. All the experimental protocols and mouse handling procedures were approved by the ethical committee of IPAB at Bahauddin Zakariya University Multan.

2.2. Murine Model of Hypoxic-Ischemic Encephalopathy. On postnatal day 10, corresponding to a brain development of full-term (40 weeks) gestational period in human fetus, male pups were anesthetized using isoflurane (3\%) inhalation. A right lateral neck incision was made, and the right common carotid artery was ligated using polypropylene falcon USP 6 suture. Pups were kept on a hot plate with constant $36^{\circ} \mathrm{C}$ temperature during the surgery. The entire surgical procedure was completed within 10 minutes. Mice were then placed for 25 minutes in a hypoxic chamber with constant flow of $8 \%$ oxygen balanced with nitrogen. The hypoxic chamber was kept in water bath to maintain the ambient temperature inside the chamber at $36^{\circ} \mathrm{C}$. Following hypoxic exposure, pups were returned back to their mothers for recovery.

2.3. Experimental Design. On the 18-20 days of life, experimental animals were separated from their parents and divided into four experimental groups. In first experiment mice were feed with diet supplemented with $2 \%$ creatine monohydrate, while control group were fed with standard rodent diet for 8 weeks following hypoxic ischemic insult on postnatal day 10 . In second and third experimental series, the same design was followed as mentioned above expect that the duration of $2 \%$ creatine monohydrate supplementation and standard diet supplementation was 12 and 15 weeks, respectively, after weaning. A separate fourth cohort of animals was used to study the effect of $2 \%$ creatine monohydrate supplementation for 12 weeks on hematology and serum biochemistry of male albino mouse without hypoxic ischemic insult.
2.4. Blood and Serum Collection. At the end of each experiment, mice were anesthetized with $3 \%$ isoflurane, and blood was sampled either from retro-orbital sinus or through direct cardiac puncture. Blood was divided into two parts; one for the study of hematological parameters and second for serum biochemical profiling.

2.5. Hematological and Serum Biochemical Analysis. Hematological parameters (blood glucose level, mean corpuscular volume, packed cell volume, total red, and white blood cell count) and serum biochemical parameters (cholesterol, aspartate transaminase (AST), alanine transaminase (ALT), high density lipoprotein (HDL), low density lipoprotein (LDL), total protein, and triglycerides) were determined in treated and untreated male albino mouse blood samples by using Hitachi 902 automatic analyzer (Japan).

2.6. Statistical Analysis. All the data is expressed as mean \pm standard deviation. Statistical package Minitab (version 13, Pennsylvania) was used for the analysis of results. Twosample $t$-test was applied to compare various parameters of hematology and serum biochemical profile of albino mouse between $2 \%$ creatine monohydrate treated and their respective untreated controls following hypoxia ischemia encephalopathy. Same statistical test was applied to compare various studied parameters between $2 \%$ creatine monohydrate treated and untreated male albino mouse.

\section{Results}

3.1. Effect of 8 Week-Creatine Monohydrate Supplementation on Blood Profile of Albino Mouse after HIE. Results indicate that all other studied parameters remained unaffected when compared with $2 \%$ creatine monohydrate treated and untreated albino mice after 8 weeks of supplementation except ALAT concentration which was significantly higher $(P>0.01)$ in creatine untreated group (Table 1$)$.

\subsection{Effect of 12 Week-Creatine Monohydrate Supplementation} on Blood Profile of Albino Mouse after HIE. When hematological and serum biochemical parameters were compared between mice supplemented with $2 \%$ creatine monohydrate for 12 weeks and their untreated control after HIE. It was observed that Cholesterol $(P>0.01)$, ALAT $(P>0.01)$ and LDL $(P=0.01)$ concentrations were significantly different in blood of creatine monohydrate treated and untreated albino mice (Table 2).

\subsection{Effect of 15 Week-Creatine Monohydrate Supplementation} on Blood Profile of Albino Mouse after HIE. Glucose $(P=$ $0.006)$ concentration was found significantly different in blood of $2 \%$ creatine monohydrate treated and untreated albino mice after 15 weeks of supplementation (Table 3 ).

\subsection{Effect of 12 Week-Creatine Monohydrate Supplementation} on Blood Profile of Albino Mouse without HIE. LDL $(P=$ 0.006) and ALAT $(P=0.006)$ concentrations were significantly different in blood of male albino mouse treated with 
TABLE 1: Comparison of various hematological and serum biochemical parameters between $2 \%$ creatine monohydrate treated and untreated (control) male albino mice for 8 weeks following hypoxia and ischemia: data is expressed as mean \pm standard deviation.

\begin{tabular}{|c|c|c|c|c|c|}
\hline \multirow{2}{*}{ Parameters } & \multicolumn{2}{|c|}{ Creatine monohydrate treated group } & \multicolumn{2}{|c|}{ Untreated control group } & \multirow{2}{*}{$P$ value } \\
\hline & Mean \pm SD & Range & Mean \pm SD & Range & \\
\hline \multicolumn{6}{|l|}{ Hematological profile } \\
\hline WBC $\left(\times 10^{9} / \mathrm{L}\right)$ & $6.006 \pm 2.648$ & $11.5-2.65$ & $5.833 \pm 3.099$ & $11.3-2.5$ & $0.901 \mathrm{~ns}$ \\
\hline $\mathrm{RBC}\left(\times 10^{12} / \mathrm{L}\right)$ & $4.96 \pm 2.62$ & $1.39-10.11$ & $5.28 \pm 1.14$ & $4.0-7.18$ & $0.748 \mathrm{~ns}$ \\
\hline PCV\% & $25.8 \pm 11.1$ & $11.3-38$ & $27.53 \pm 8.27$ & $12.2-42.5$ & $0.731 \mathrm{~ns}$ \\
\hline Glucose (mg/dL) & $161.1 \pm 38.4$ & $98-214$ & $136.2 \pm 19.1$ & $101-156$ & $0.142 \mathrm{~ns}$ \\
\hline MCV (fp) & $84.6 \pm 85.4$ & $29.6-258.2$ & $53.0 \pm 15.4$ & $27.8-78.2$ & $0.370 \mathrm{~ns}$ \\
\hline \multicolumn{6}{|l|}{ Serum biochemical profile } \\
\hline Total protein $(\mathrm{g} / \mathrm{dL})$ & $38.00 \pm 9.17$ & $28-46$ & $53.00 \pm 1.00$ & $53-54$ & $0.106 \mathrm{~ns}$ \\
\hline Triglycerides (mg/dL) & $234 \pm 125$ & $130-393$ & $280 \pm 140$ & $201-410$ & $0.646 \mathrm{~ns}$ \\
\hline Cholesterol (mg/dL) & $824 \pm 196$ & $489-984$ & $579 \pm 208$ & $411-811$ & $0.174 \mathrm{~ns}$ \\
\hline $\mathrm{HDL}(\mathrm{mg} / \mathrm{dL})$ & $49.00 \pm 3.00$ & $46-52$ & $49 \pm 1.00$ & $48-50$ & $1.000 \mathrm{~ns}$ \\
\hline $\mathrm{LDL}(\mathrm{mg} / \mathrm{dL})$ & $662 \pm 237$ & $411-883$ & $482 \pm 222$ & $283-722$ & $0.408 \mathrm{~ns}$ \\
\hline $\operatorname{ALAT}(\mu / \mathrm{L})$ & $23.67 \pm 9.07$ & $14-32$ & $248.67 \pm 8.08$ & $240-256$ & $P>0.001^{* * *}$ \\
\hline $\operatorname{ASAT}(\mathrm{u} / \mathrm{L})$ & $156.0 \pm 16.4$ & $138-170$ & $142.0 \pm 20.0$ & $122-162$ & $0.417 \mathrm{~ns}$ \\
\hline
\end{tabular}

$P<0.05$ = non-significant (ns), ${ }^{* * *} P>0.001$ = highly significant.

TABLE 2: Comparison of various hematological and serum biochemical parameters between $2 \%$ creatine monohydrate treated and untreated (control) male albino mice for 12 weeks following hypoxia and ischemia: data is expressed as mean \pm standard deviation.

\begin{tabular}{|c|c|c|c|c|c|}
\hline \multirow{2}{*}{ Parameters } & \multicolumn{2}{|c|}{ Creatine monohydrate treated group } & \multicolumn{2}{|c|}{ Untreated control group } & \multirow{2}{*}{$P$ value } \\
\hline & Mean \pm SD & Range & Mean \pm SD & Range & \\
\hline \multicolumn{6}{|l|}{ Hematological profile } \\
\hline WBC $\left(\times 10^{9} / \mathrm{L}\right)$ & $5.91 \pm 2.85$ & $3.4-10.7$ & $9.170 \pm 6.518$ & $5.15-20.5$ & $0.347 \mathrm{~ns}$ \\
\hline $\mathrm{RBC}\left(\times 10^{12} / \mathrm{L}\right)$ & $6.79 \pm 2.74$ & $4.59-10.86$ & $6.76 \pm 2.60$ & $3.95-9.61$ & $0.985 \mathrm{~ns}$ \\
\hline PCV\% & $27.83 \pm 7.41$ & $19.2-39.5$ & $25.03 \pm 5.42$ & $20-33$ & $0.492 \mathrm{~ns}$ \\
\hline Glucose (mg/dL) & $169.5 \pm 78.8$ & $101-280$ & $115.8 \pm 40.2$ & $60-162$ & $0.188 \mathrm{~ns}$ \\
\hline $\operatorname{MCV}(f p)$ & $47.1 \pm 22.8$ & $19.8-80.4$ & $40.3 \pm 11.9$ & $26-50.6$ & $0.544 \mathrm{~ns}$ \\
\hline \multicolumn{6}{|l|}{ Serum biochemical profile } \\
\hline Total protein $(\mathrm{g} / \mathrm{dL})$ & $3.2 \pm 0.1$ & $3.1-3.3$ & $34.7 \pm 27.3$ & $17.4-66.1$ & $0.184 \mathrm{~ns}$ \\
\hline Triglycerides (mg/dL) & $427 \pm 314$ & $65-616$ & $305.3 \pm 68.0$ & $228-356$ & $0.579 \mathrm{~ns}$ \\
\hline Cholesterol (mg/dL) & $358.4 \pm 32.4$ & $318-394$ & $753.3 \pm 33.1$ & $722-788$ & $P>0.001^{* * *}$ \\
\hline $\mathrm{HDL}(\mathrm{mg} / \mathrm{dL})$ & $20.67 \pm 4.04$ & $17-25$ & $35.0 \pm 20.0$ & $18-57$ & $0.347 \mathrm{~ns}$ \\
\hline $\mathrm{LDL}(\mathrm{mg} / \mathrm{dL})$ & $240.3 \pm 72.5$ & $173-317$ & $656.7 \pm 21.9$ & $632-674$ & $0.011^{*}$ \\
\hline $\operatorname{ALAT}(\mu / \mathrm{L})$ & $72.33 \pm 6.81$ & $67-80$ & $191.7 \pm 10.4$ & $180-200$ & $P>0.001^{* * *}$ \\
\hline $\operatorname{ASAT}(\mathrm{u} / \mathrm{L})$ & $231.7 \pm 10.4$ & $22-240$ & $161.7 \pm 22.5$ & $140-185$ & $0.639 \mathrm{~ns}$ \\
\hline
\end{tabular}

$P<0.05=$ non-significant (ns), ${ }^{*} P>0.05=$ Least significant, ${ }^{* * *} P>0.001=$ highly significant.

$2 \%$ creatine monohydrate for 12 weeks when compared with creatine untreated male albino mice (Table 4).

\section{Discussion}

The decreased tissue oxygen supply below the normal level is called hypoxia while reduced blood flow to organ when cerebral artery is blocked by a clot is called ischemia. During hypoxia, reactive oxygen specie (ROS) formation is increased and leads to stress oxidative condition [19]. Blood is an important medium in assessing the health [20], and physiological and pathological conditions of animals can be assessed by the evaluation of hematological and biochemical analyses of the blood [21]. The present study was designed to evaluate the effect of $2 \%$ creatine monohydrate supplementation on the blood chemistry and hematology of albino mouse under hypoxic ischemic and nonhypoxic ischemic conditions.

Our results indicated that creatine supplementation after hypoxic and ischemic insult has no effect on studied hematological parameters of blood, as there was no significant difference in hematological parameters when compared with $2 \%$ 
TABLE 3: Comparison of various hematological and serum biochemical parameters between $2 \%$ creatine monohydrate treated and untreated (control) male albino mice for 15 weeks following hypoxia and ischemia: data is expressed as mean \pm standard deviation.

\begin{tabular}{|c|c|c|c|c|c|}
\hline \multirow{2}{*}{ Parameters } & \multicolumn{2}{|c|}{ Creatine monohydrate treated Group } & \multicolumn{2}{|c|}{ Untreated control group } & \multirow{2}{*}{$P$ value } \\
\hline & Mean \pm SD & Range & Mean \pm SD & Range & \\
\hline \multicolumn{6}{|l|}{ Hematological profile } \\
\hline $\mathrm{WBC}\left(\times 10^{9} / \mathrm{L}\right)$ & $9.94 \pm 5.64$ & $3.2-17.4$ & $9.94 \pm 1.66$ & $7.4-11.8$ & $0.806 \mathrm{~ns}$ \\
\hline $\mathrm{RBC}\left(\times 10^{12} / \mathrm{L}\right)$ & $7.512 \pm 0.963$ & $6.25-9.03$ & $7.55 \pm 2.98$ & $2.77-10.58$ & $0.977 \mathrm{~ns}$ \\
\hline PCV\% & $31.5 \pm 13.1$ & $13.5-52.3$ & $29.11 \pm 9.66$ & $14.2-41.6$ & $0.681 \mathrm{~ns}$ \\
\hline Glucose (mg/dL) & $177.8 \pm 18.4$ & $150-205$ & $211 \pm 21$ & $176-245$ & $0.006^{* *}$ \\
\hline $\operatorname{MCV}(\mathrm{fp})$ & $42.5 \pm 17.2$ & $15-71.6$ & $53.9 \pm 47.9$ & $13.4-150$ & $0.570 \mathrm{~ns}$ \\
\hline \multicolumn{6}{|l|}{ Serum biochemical profile } \\
\hline Total protein $(\mathrm{g} / \mathrm{dL})$ & $3.83 \pm 0.93$ & $2.5-5$ & $2.80 \pm 1.66$ & $1.6-4.7$ & $0.423 \mathrm{~ns}$ \\
\hline Triglycerides (mg/dL) & $210 \pm 146$ & $59-399$ & $331 \pm 79.2$ & $240-399$ & $0.188 \mathrm{~ns}$ \\
\hline Cholesterol (mg/dL) & $178 \pm 131$ & 75-399 & $315 \pm 192$ & $129-513$ & $0.356 \mathrm{~ns}$ \\
\hline $\mathrm{HDL}(\mathrm{mg} / \mathrm{dL})$ & $31.00 \pm 3.00$ & $28-34$ & $28.00 \pm 8.00$ & $20-36$ & $0.605 \mathrm{~ns}$ \\
\hline $\mathrm{LDL}(\mathrm{mg} / \mathrm{dL})$ & $69.7 \pm 46.0$ & $25-117$ & $221 \pm 169$ & $60-397$ & $0.110 \mathrm{~ns}$ \\
\hline $\operatorname{ASAT}(\mu / \mathrm{L})$ & $227.7 \pm 60.1$ & $162-280$ & $608 \pm 330$ & $144-889$ & $0.110 \mathrm{~ns}$ \\
\hline $\operatorname{ALAT}(\mu / \mathrm{L})$ & $40.8 \pm 30.6$ & $20-86$ & $100.5 \pm 76.2$ & $42-208$ & $0.242 \mathrm{~ns}$ \\
\hline
\end{tabular}

$P<0.05=$ non-significant $(\mathrm{ns}),{ }^{* *} P>0.01=$ significant.

TABLE 4: Comparison of various hematological and serum biochemical parameters between $2 \%$ creatine monohydrate treated and untreated (control) male albino mice for 12 weeks: data is expressed as mean \pm standard deviation.

\begin{tabular}{|c|c|c|c|c|c|}
\hline \multirow{2}{*}{ Parameters } & \multicolumn{2}{|c|}{ Creatine monohydrate treated group $(N=10)$} & \multicolumn{2}{|c|}{ Untreated control group $(N=10)$} & \multirow{2}{*}{$P$ value } \\
\hline & Mean \pm SD & Range & Mean \pm SD & Range & \\
\hline \multicolumn{6}{|l|}{ Hematological profile } \\
\hline $\operatorname{WBC}\left(\times 10^{9} / \mathrm{L}\right)$ & $4.3 \pm 1.5$ & $2.5-8.5$ & $8.3 \pm 2.6$ & $4.6-13.3$ & $0.302 \mathrm{~ns}$ \\
\hline $\mathrm{RBC}\left(\times 10^{12} / \mathrm{L}\right)$ & $5.69 \pm 3.14$ & $2.9-13.8$ & $5.85 \pm 2.67$ & $2.1-10.5$ & $0.903 \mathrm{~ns}$ \\
\hline PCV\% & $25.13 \pm 5.58$ & $17.3-34.8$ & $28.0 \pm 10.1$ & $11.4-45.5$ & $0.467 \mathrm{~ns}$ \\
\hline Glucose $(\mathrm{mg} / \mathrm{dL})$ & $146.4 \pm 23.2$ & $107-193$ & $156.1 \pm 60.5$ & $78-289$ & $0.659 \mathrm{~ns}$ \\
\hline MCV (fp) & $55.1 \pm 27.3$ & $12.3-97.2$ & $61.0 \pm 45.3$ & $20.1-150$ & $0.740 \mathrm{~ns}$ \\
\hline \multicolumn{6}{|l|}{ Serum biochemical profile } \\
\hline Total protein $(\mathrm{g} / \mathrm{dL})$ & $5.27 \pm 1.23$ & $3.9-6.3$ & $40.9 \pm 27.9$ & $12.5-78.8$ & $0.084 \mathrm{~ns}$ \\
\hline Triglycerides (mg/dL) & $226.3 \pm 16.2$ & $216-245$ & $395.0 \pm 93.8$ & $334-503$ & $0.092 \mathrm{~ns}$ \\
\hline Cholesterol (mg/dL) & $376 \pm 283$ & $176-791$ & $765 \pm 118$ & $629-839$ & $0.068 \mathrm{~ns}$ \\
\hline $\mathrm{HDL}(\mathrm{mg} / \mathrm{dL})$ & $35.75 \pm 9.22$ & $23-45$ & $20.67 \pm 2.08$ & $19-23$ & $0.051 \mathrm{~ns}$ \\
\hline $\mathrm{LDL}(\mathrm{mg} / \mathrm{dL})$ & $152.6 \pm 64.7$ & $735-742$ & $666 \pm 107$ & $94-222$ & $0.006^{* *}$ \\
\hline $\operatorname{ALAT}(\mu / \mathrm{L})$ & $55.33 \pm 5.03$ & $50-60$ & $81.00 \pm 3.61$ & $78-85$ & $0.006^{* *}$ \\
\hline $\operatorname{ASAT}(\mathrm{u} / \mathrm{L})$ & $215.7 \pm 46.7$ & $165-257$ & $157.33 \pm 6.35$ & $150-161$ & $0.165 \mathrm{~ns}$ \\
\hline
\end{tabular}

$P<0.05=$ non-significant $(\mathrm{ns}),{ }^{* *} P>0.01=$ significant.

creatine monohydrate supplemented and untreated control group after 8,12 , and 15 weeks of $2 \%$ creatine monohydrate supplementation (Tables 1, 2, and 3). Similar results were obtained in nonhypoxic ischemic group when hematological parameters were compared in male albino mouse on normal rodent diet with mouse supplemented with $2 \%$ creatine monohydrate for 12 weeks (Table 4). Our results are in agreement with Eijnde et al. [22] who had reported that all values of blood hematology in human males following creatine supplementation remained within the normal clinical range throughout the study with no significant difference.

In $2 \%$ creatine monohydrate supplemented albino mouse, for 15 weeks, after hypoxic ischemic insult, blood glucose level was lower $(177.8 \pm 18.4)$ as compared with the creatine untreated control group $(211 \pm 21)$, and the difference was statistically significant $(P=0.006)$ (Table 3$)$. Decreased glucose level after creatine supplementation was possibly due to the fact that creatine supplementation leads to increased 
insulin production confirming the findings of Rooney et al. [23] who had reported that chronic supplementation of creatine leads to hyper secretion of insulin decreasing the blood glucose concentrations.

Our results revealed that mouse exposed to hypoxicischemic insult had high serum cholesterol level when compared with non-hypoxic ischemic group. Our results are consistent with the results of $\mathrm{Li}$ et al. [24, 25] who had reported that hypoxia is one of the key mechanism which leads to the hyperlipidemia. Similar results were also documented by Savransky et al. [26] as they observed that hypoxia raises serum cholesterol and LDL-C levels in mice fed on a regular diet. In creatine supplemented hypoxicischemic mouse blood cholesterol level was lower (358.4 \pm 32.4) as compared with normal diet fed controls (753.3 \pm 33.1), and this difference was statistically highly significant $(P=P>0.01)$ (Table 2). Earnest et al. [27] reported effect of Cr supplementation on the plasma lipid profile in human males and females and observed that individuals with high basal cholesterol levels exhibited a reduction in blood total cholesterol following creatine supplementation.

Our results indicated that mouse that suffers from hypoxia and ischemia had high ALAT level as compared with their uninsulted control group. Increased ALAT level after hypoxia was also reported by Savransky et al. [26] while investigating the effects of hypoxia on the liver in the absence of obesity. Statistically significant difference in ALAT level was observed in hypoxic ischemic mouse after 8 weeks $(P=$ $P>0.01)$ (Table 1$)$ and 12 weeks $(P=P>0.01)$ (Table 2$)$ of creatine supplementation as compared with their normal diet fed mouse. ALAT variation was also observed in the group without hypoxia and ischemia, In creatine supplemented mouse ALAT level was lower $(55.33 \pm 5.03)$ as compared with untreated control group $(81.00 \pm 3.61)$, and this result was statistically significant $(P=0.006)$ (Table 4$)$ indicating that creatine supplementation improves the liver functioning in albino mouse.

\section{Conclusion}

Our results indicated that creatine supplementation after hypoxic and ischemic insult has no effect on studied hematological parameters of blood while serum biochemical profile is significantly affected by hypoxia ischemia, and in creatine monohydrate treated groups, studied parameters had concentrations lower than untreated groups indicating that creatine supplementation maintains serum profile as higher values of certain enzymes like ALAT are indicators of abnormal physiology.

\section{Conflict of Interests}

The authors have no conflict of interests.

\section{Authors' Contribution}

Shahid Iqbal and Nabia Nazir contributed equally to this paper.

\section{Acknowledgment}

The authors are grateful to the Higher Education Commission (HEC) of Pakistan for providing research grant for this study under the Indigenous Ph.D. Scholarship Scheme.

\section{References}

[1] V. Pierrat, N. Haouari, A. Liska, D. Thomas, D. Subtil, and P. Truffert, "Prevalence, causes, and outcome at 2 years of age of newborn encephalopathy: population based study," Archives of Disease in Childhood, vol. 90, no. 3, pp. F257-F261, 2005.

[2] A. R. Walmsley and A. K. Mir, "Targeting the Nogo-a signalling pathway to promote recovery following acute CNS injury," Current Pharmaceutical Design, vol. 13, no. 24, pp. 2470-2484, 2007.

[3] A. V. Karasev, S. V. Lebedev, T. V. Garats et al., "Monitoring of motor disorders in 7-day-old rats with severe hypoxicischemic injury of the brain," Bulletin of Experimental Biology and Medicine, vol. 149, no. 6, pp. 677-681, 2010.

[4] P. S. Boggio, E. Coutinho de Macedo, A. Pascual-Leone, J. M. Tormos Muñoz, J. S. SchWartzman, and F. Fregni, "Neuromodulation in hypoxic-ischemic injury," Brain Stimulation, vol. 2, no. 3, pp. 179-181, 2009.

[5] C. Kaur, W. S. Foulds, and E. A. Ling, "Hypoxia-ischemia and retinal ganglion cell damage," Clinical Ophthalmology, vol. 2, pp. 879-889, 2008.

[6] F. J. Northington, R. Chavez-Valdez, and L. J. Martin, "Neuronal cell death in neonatal hypoxia-ischemia," Annals of Neurology, vol. 69, no. 5, pp. 743-758, 2011.

[7] J. Parkash and N. Das, "Pattern of admission to neonatal unit," Journal of the College of Physicians and Surgeons Pakistan, vol. 15, no. 6, pp. 341-344, 2005.

[8] Z. A. Bhutta, "Priorities in newborn care and development of clinical neonatology in Pakistan: where to now?" Journal of the College of Physicians and Surgeons-Pakistan, vol. 7, pp. 231-234, 1997.

[9] M. C. Bianchi, M. Tosetti, F. Fornai et al., "Reversible brain creatine deficiency in two sisters with normal blood creatine level," Annals of Neurology, vol. 47, pp. 511-513, 2000.

[10] M. G. Bemben and H. S. Lamont, "Creatine supplementation and exercise performance: recent findings," Sports Medicine, vol. 35, no. 2, pp. 107-125, 2005.

[11] R. L. Terjung, P. Clarkson, E. R. Eichner et al., "American College of Sports Medicine roundtable. The physiological and health effects of oral creatine supplementation," Medicine and Science in Sports and Exercise, vol. 32, no. 3, pp. 706-717, 2000.

[12] M. Wyss and A. Schulze, "Health implications of creatine: can oral creatine supplementation protect against neurological and atherosclerotic disease?" Neuroscience, vol. 112, no. 2, pp. 243260, 2002.

[13] A. Watanabe, N. Kato, and T. Kato, "Effects of creatine on mental fatigue and cerebral hemoglobin oxygenation," Neuroscience Research, vol. 42, no. 4, pp. 279-285, 2002.

[14] P. G. Sullivan, J. D. Geiger, M. P. Mattson, and S. W. Scheff, "Dietary supplement creatine protects against traumatic brain injury," Annals of Neurology, vol. 48, pp. 723-729, 2000.

[15] S. Zhu, M. Li, B. E. Figueroa et al., "Prophylactic creatine administration mediates neuroprotection in cerebral ischemia in mice," Journal of Neuroscience, vol. 24, no. 26, pp. 5909-5912, 2004. 
[16] O. A. Andreassen, A. Dedeoglu, R. J. Ferrante et al., "Creatine increases survival and delays motor symptoms in a transgenic animal model of Huntington's disease," Neurobiology of Disease, vol. 8, no. 3, pp. 479-491, 2001.

[17] A. Dedeoglu, J. K. Kubilus, L. Yang et al., "Creatine therapy provides neuroprotection after onset of clinical symptoms in Huntington's disease transgenic mice," Journal of Neurochemistry, vol. 85, no. 6, pp. 1359-1367, 2003.

[18] S. M. Hersch, S. Gevorkian, K. Marder et al., "Creatine in Huntington disease is safe, tolerable, bioavailable in brain and reduces serum $8 \mathrm{OH}_{2}$ 'dG,' Neurology, vol. 66, no. 2, pp. 250-252, 2006.

[19] A. J. Giaccia, M. C. Simon, and R. Johnson, "The biology of hypoxia: the role of oxygen sensing in development, normal function, and disease," Genes and Development, vol. 18, no. 18, pp. 2183-2194, 2004.

[20] K. Satue, A. Hernandez, and A. Munoz, "Physiological factors in the interpretation of equine hematological profile," in Hematology-Science and Practice, 2011.

[21] B. M. Bush, Interpretation of Laboratory Results for Small Animal, Blackwell, London, UK, 1991.

[22] B. O. Eijnde, M. Van Leemputte, M. Goris et al., "Effects of creatine supplementation and exercise training on fitness in men 55-75 yr old," Journal of Applied Physiology, vol. 95, no. 2, pp. 818-828, 2003.

[23] K. Rooney, J. Bryson, J. Phuyal, G. Denyer, I. Caterson, and C. Thompson, "Creatine supplementation alters insulin secretion and glucose homeostasis in vivo," Metabolism, vol. 51, no. 4, pp. 518-522, 2002.

[24] J. Li, L. N. Thorne, N. M. Punjabi et al., "Intermittent hypoxia induces hyperlipidemia in lean mice," Circulation Research, vol. 97, no. 7, pp. 698-706, 2005.

[25] J. Li, V. Savransky, A. Nanayakkara, P. L. Smith, C. P. O’Donnell, and V. Y. Polotsky, "Hyperlipidemia and lipid peroxidation are dependent on the severity of chronic intermittent hypoxia," Journal of Applied Physiology, vol. 102, no. 2, pp. 557-563, 2007.

[26] V. Savransky, A. Nanayakkara, A. Vivero et al., "Chronic intermittent hypoxia predisposes to liver injury," Hepatology, vol. 45, no. 4, pp. 1007-1013, 2007.

[27] C. P. Earnest, A. L. Almada, and T. L. Mitchell, "Highperformance capillary electrophoresis-pure creatine monohydrate reduces blood lipids in men and women," Clinical Science, vol. 91, no. 1, pp. 113-118, 1996. 

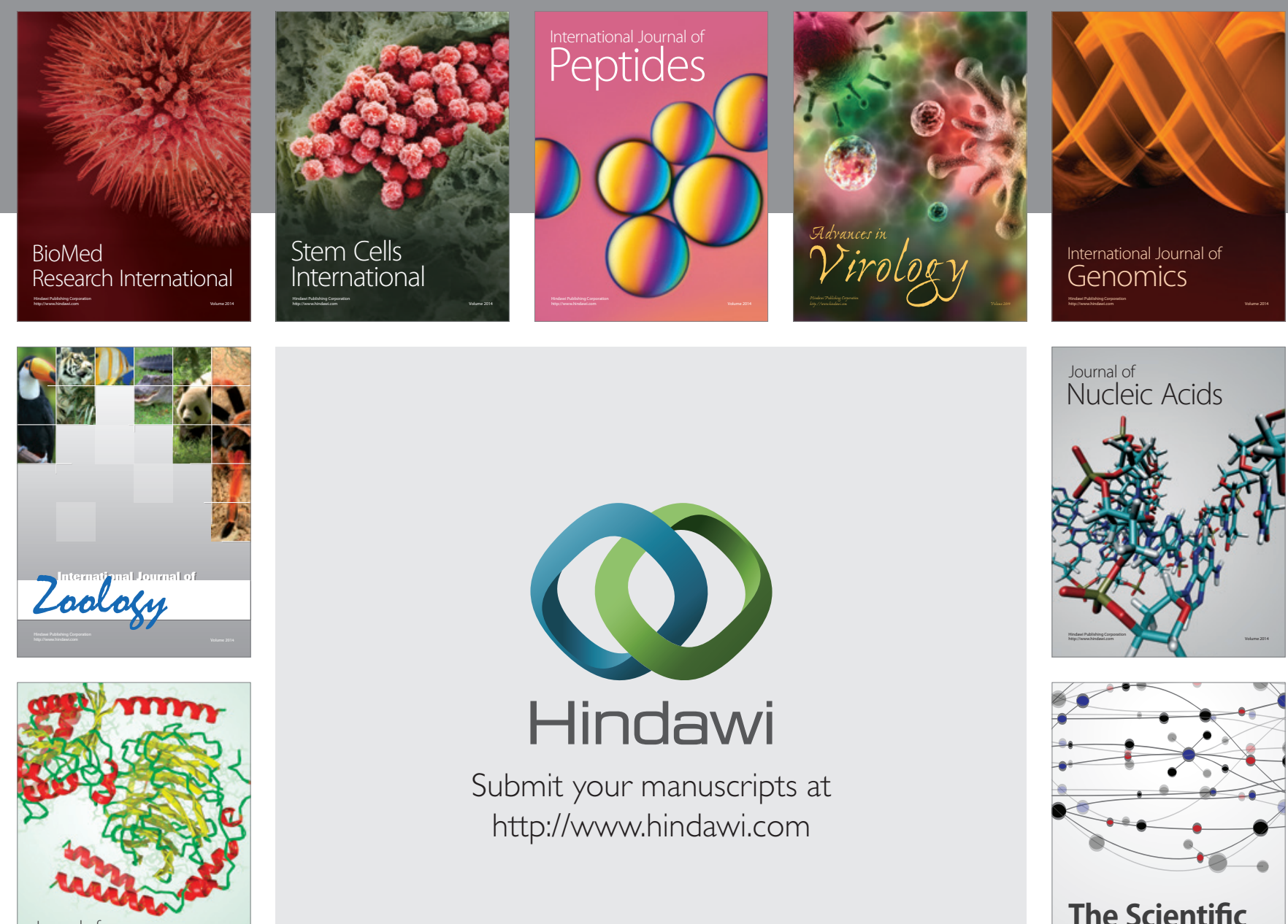

Submit your manuscripts at

http://www.hindawi.com

Journal of
Signal Transduction
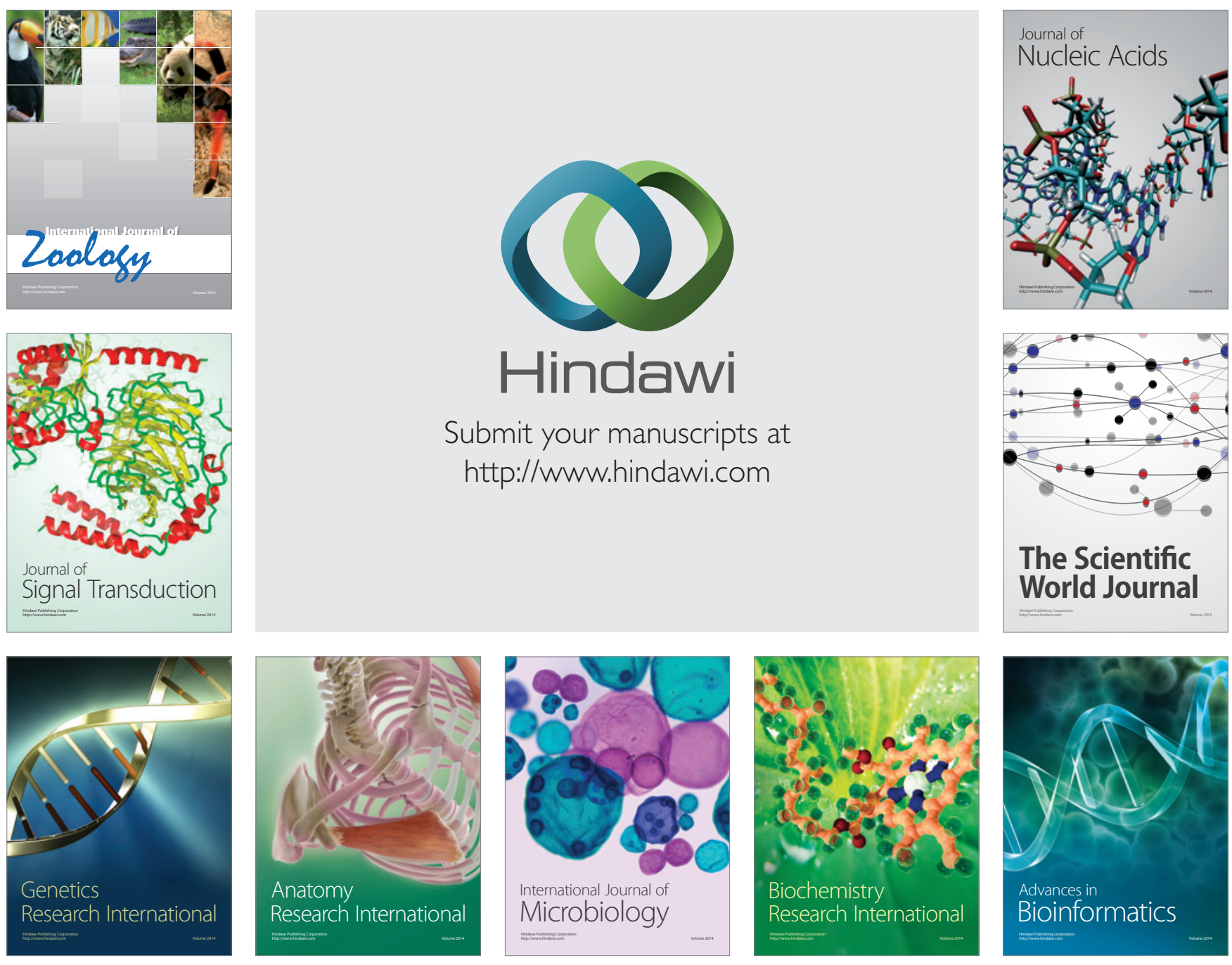

The Scientific World Journal
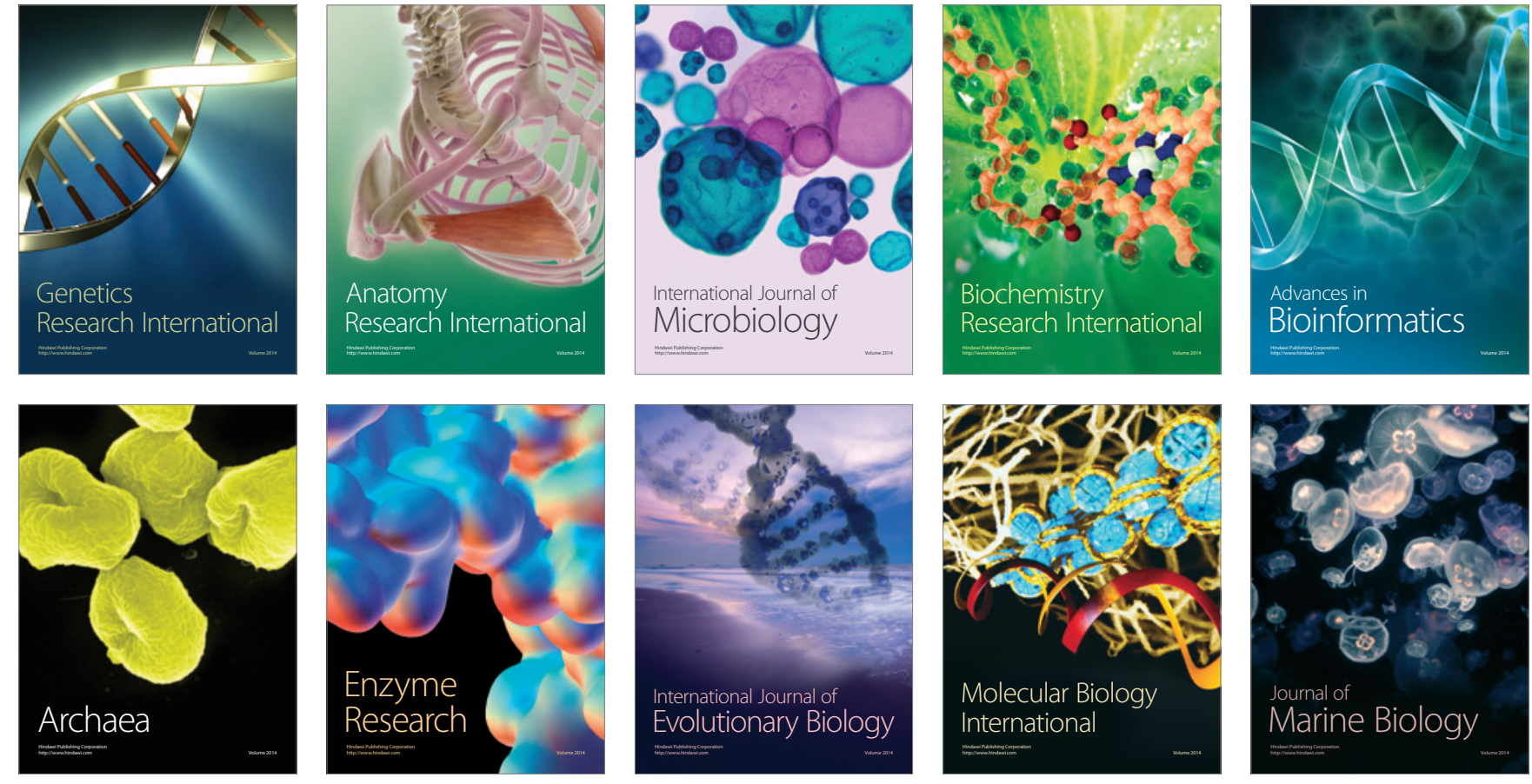